\title{
Pengaturan Hukum Interasional Terhadap Penggunaan Nuklir Untuk Tujuan Damai
}

\author{
Widya Krulinasari
}

Dosen Bagian Hukum Internasional Fakultas Hukum Unila

\begin{abstract}
Abstrak
Penggunaan tenaga nuklir tidak hanya menimbulkan efek yang bermanfaaat dan berguna bagi kehidupan masyarakat negara penggunanya. Tenaga nuklir juga dapat mengakibatkan dampak yang sangat buruk bagi makhluk hidup maupun lingkungan apabila tidak digunakan dengan hati-hati. Hukum internasional mengatur penggunaan nuklir untuk tujuan damai sebagaimana diatur dalam Pasal 13 butir 1 bagian b Piagam Perserikatan Bangsa-Bangsa, dengan alasan tidak bertentangan dengan tujuan-tujuan dan prinsip-prinsip dasar yang termuat di dalam Perserikatan Bangsa-Bangsa. Selain itu juga diatur dalam Convention on Nuclear Safety (Konvensi Tentang Keselamatan Nuklir) dan The Convention on the Physical Protection of Nuclear Material (Konvensi Tentang Perlindungan Fisik Bahan Nuklir).
\end{abstract}

Kata kunci: tenaga nuklir, tujuan damai, konvensi

\section{Pendahuluan}

Perkembangan ilmu dan teknologi saat ini berkembang dengan sangat pesat, termasuk perkembangan tenaga nuklir dalam hal penggunaannya. Perkembangan teknologi nuklir juga tidak terlepas dari kondisi dan situasi politik dunia yang pada saat terjadinya perang dunia menyebabkan perkembangan teknologi nukir mengarah kepada pembuatan senjata untuk perang berupa bom nuklir. Bermula dari kenyataan inilah istilah nuklir seringkali dikaitkan dengan senjata. ${ }^{1}$

Penggunaan tenaga nuklir sebagai senjata untuk perang telah membawa dampak yang buruk bagi umat manusia, bagi perdamaian dan keamanan dunia, yang bertentangan

1 Mukhlis Akhadi, Pengantar Teknologi Nuklir, (Jakarta: Rineka Cipta, 1997), hlm.10. dengan tujuan dan prinsip-prinsip dasar yang termuat dalam Piagam Perserikatan Bangsa-Bangsa. Pasal 1 butir 1 Piagam Perserikatan BangsaBangsa mengatur bahwa salah satu tujuan Perserikatan Bangsa-Bangsa adalah memelihara perdamaian dan keamanan internasional dan untuk tujuan itu, mengadakan tindakantindakan bersama yang efektif untuk mencegah dan melenyapkan ancaman-ancaman terhadap pelanggaran-pelanggaran terhadap perdamaian tersebut. Ketentuan dalam Piagam Perserikatan Bangsa-Bangsa ini bukan berarti penelitian dan penggunaan tenaga nuklir dilarang, Perserikatan Bangsa-Bangsa tetap memberi ruang terhadap kemajuan di bidang pendidikan termasuk di bidang teknologi seperti yang dimuat di dalam Pasal 13 butir 1 bagian $b$ Piagam Perserikatan Bangsa-Bangsa, dengan alasan tidak bertentangan dengan tujuan-tujuan dan prinsip- 
prinsip dasar yang termuat di dalam Perserikatan Bangsa-Bangsa.

Hukum Internasional tidak melarang pemanfaatan tenaga nuklir untuk tujuan damai, namun selain pemanfaatannya harus untuk tujuan damai, pemanfaatan tenaga nuklir harus memeperhatikan semboyan atau azas keselamatan pemanfaatan nuklir, yaitu pemanfaatan tenaga nuklir harus mendapat pengawasan yang cermat agar selalu mengikuti segala ketentuan di bidang keselamatan tenaga nuklir sehingga pemanfaatan tenaga nuklir tersebut tidak menimbulkan bahaya radiasi terhadap pekerja, masyarakat, dan lingkungan hidup. $^{2}$ Dalam hal pemanfaatan nuklir, azas demikian menjadi satu hal yang sungguhsunguh sangat diperhatikan, karena sesuai tuntutan pemanfaatannya, teknologi nuklir harus didukung keselamatan yang amat ketat agar dapat beroperasi secara aman dan terkendali. Pada umumnya tiap negara tentu memiliki pola atau ketentuan nasional yang mengatur aspek keselamatan nuklir di negaranya masing-masing.

Penggunaan tenaga nuklir tidak hanya menimbulkan efek yang bermanfaaat dan berguna bagi kehidupan masyarakat negara penggunanya. Tenaga nuklir juga dapat mengakibatkan dampak yang sangat buruk bagi makhluk hidup maupun lingkungan apabila tidak digunakan dengan hati-hati. Salah satu contoh nyata dampak buruk yang timbul dari penyalahgunaan dan kecerobohan manusia adalah kasus

\footnotetext{
${ }^{2}$ Penjelasan atas Undang-Undang Republik Indonesia Nomor 10 Tahun 1997 Tentang ketenaganukliran, diakses dari: http://www.batan.go.id/prod_hukum/pnjelas _uu_tenuk.php. pada 13 September 2011
}

Chernobyl, yakni sebuah kecelakaan pada PLTN Chernobyl yang terletak di Ukraina, dimana reaktor nuklir tersebut meledak pada Tanggal 26 April 1986 yang menimbulkan dampak radiasi nuklir yang sangat berbahaya dan menurut laporan WHO telah menimbulkan sangat banyak korban jiwa yang meninggal seketika dan juga bertahun-tahun setelahnya akibat radiasi nuklir tersebut, dan diantara penyakit yang banyak ditemukan adalah kanker. ${ }^{3}$

Suatu peristiwa kecelakaan nuklir yang tidak hanya berdampak di negara bersangkutan, tapi juga berdampak pada negara tetangga bahkan negara yang lebih jauh memicu pembicaraan seluruh dunia tentang kepantasan skema pertanggungjawaban nuklir yang ada. Dalam periode Tahun 1988 sampai Tahun 2004, perundinganperundingan berlangsung untuk mempertimbangkan pengalaman Chernobyl dan untuk memperkuat hukum internasional tentang penggunaan nuklir. Peristiwa Chernobyl telah memicu suatu tindakan segera yang berkelanjutan dan komprehensif dari masyarakat internasional yang menghasilkan sejumlah instrumen internasional baru yang ditujukan untuk menghindari atau mengatasi kelemahan rezim hukum internasional pra-1986 yang terbukti tidak berjalan efektif. ${ }^{4}$

\footnotetext{
3 Inilah Dampak Radiasi Nuklir Bagi Manusia, diakses dari: http://news.okezone.com/read/2011/03/16/3 37/435349/inilah-dampak-radiasi-nuklirbagi-manusia. Pada 22 April 2011

4 Perjanjian Internasional Ketenaganukliran Pada Penggunaan Nuklir Tujuan Damai, diakses dari: http://sainsindonesia.wordpress.com/2010/10/06/perjanjian-internasio-
} 
Penggunaan tenaga nuklir juga menuntut sebuah tanggungjawab yang besar, yakni keselamatan dan keamanan yang tinggi, rawan terhadap penyimpangan untuk senjata, dan rawan digunakan untuk kejahatan teroris. Oleh karenanya, demi mencegah terjadinya penyalahgunaan tenaga nuklir, masyarakat internasional mendirikan suatu badan internasioanal di bawah naungan Perserikatan Bangsa-Bangsa (PBB), yaitu Badan Tenaga Atom Internasional (International Atomic Energy Agency/IAEA). IAEA adalah sebuah organisasi independent yang didirikan pada Tanggal 29 Juli 1957 bermarkas di Wina Austria dengan tujuan mempromosikan penggunaan energi nuklir secara damai serta menangkal penggunaannya untuk keperluan militer. ${ }^{5}$

Dari uraian di atas, permasalahan yang diambil adalah bagaimana pengaturan hukum internasional dalam hal penggunaan nuklir untuk tujuan damai.

\section{Pembahasan}

Tahun 1896, Antoine Henri Becquerel menemukan radioaktivitas uranium. Pada Tahun 1902, Marie dan Pierre Curie mengisolasi logam radioaktif disebut radium Pada Tahun 1905, Albert Einstein merumuskan dalam teori Teori Relativitas Khusus. Menurut teori ini, massa dapat dianggap sebagai bentuk lain dari energi. Menurut Einstein, kita bisa mengubah massa

nal-ketenaganukliran-pada-penggunaannuklir-tujuan-damai/. Pada 3 Mei 2011

${ }^{5}$ Badan Tenaga Atom Internasional, diakses dari: hattp://id.wikipedia.org/wiki/Badan _ Tenaga_Atom_Internasional. Pada 24 April 2011 menjadi energi, mungkin untuk "membebaskan" sejumlah besar energi. Selama dekade berikutnya, langkah besar diambil oleh Ernest Rutherford dan Niels Bohr menjelaskan struktur atom yang lebih tepat. Mereka mengatakan, dari inti bermuatan positif, dan elektron bermuatan negatif yang berputar di sekitar inti. Itu adalah inti, para ilmuwan menyimpulkan, bahwa harus dipecah atau "meledak" jika energi atom akan dirilis. ${ }^{6}$

Tahun 1934, Enrico Fermi Italia menghancurkan atom berat dengan menyemprotkannya pada Neutron, namun dia tidak menyadari bahwa ia telah memperoleh fisi nuklir. Pada Tahun 1938, meskipun, Otto Hahn dan Fritz Strassman di Berlin melakukan eksperimen serupa dengan Uranium dan menjadi prestasi dunia, mereka telah menghasilkan fisi nuklir dan telah memisahkan atom, yaitu 33 tahun setelah Einstein mengatakan bahwa massa berubah menjadi energi. Pada Tanggal 2 Agustus 1939, Albert Einstein menulis surat kepada Presiden Amerika, Franklin D. Roosevelt. Dia mendesak Roosevelt untuk memulai program nuklir secepatnya. Selama empat bulan terakhir, Albert Einstein telah membuat kemungkinan untuk mengatur reaksi nuklir dalam sebuah massa besar Uranium. Dan fenomena baru ini yang akan mengarah pada pembuatan bom. Pada Bulan Desember 1942 di University of Chicago, ahli fisika Italia Enrico Fermi berhasil menghasilkan reaksi berantai nuklir pertama. Hal ini

\footnotetext{
${ }^{6}$ Sejarah Terciptanya Bom Nuklir, diakses dari: http://www.centralartikel.com/2010/10/ sejarah-terciptanya-bom-nuklir.html. pada 1 Mei 2011
} 
dilakukan dengan pengaturan Uranium alam gumpalan didistribusikan dalam setumpuk besar grafit murni, suatu bentuk karbon. Dalam reaktor nuklir, moderator grafit berfungsi untuk memperlambat Neutron. ${ }^{7}$

Amerika Serikat selama Perang Dunia II pada Bulan Agustus 1942, mendirikan Proyek Manhattan. Tujuan dari proyek ini adalah untuk mengembangkan, membangun, dan menguji bom. Banyak ilmuwan Amerika terkemuka, termasuk fisikawan Enrico Fermi dan J. Robert Oppenheimer dan kimia Harold Urey, yang terkait dengan proyek, yang dipimpin oleh seorang insinyur Angkatan Darat AS, Brigadir Jenderal Leslie R. Groves. Pada Tanggal 16 Juli 1945, bom atom pertama atau A-bom, diuji di Alamogordo, New Mexico. Pada Tanggal 6 Agustus 1945, Enola Gay, pesawat Amerika, menjatuhkan bom atom pertama yang pernah digunakan dalam peperangan di Hiroshima, Jepang, akhirnya menewaskan lebih dari 140.000 orang. Pada Tanggal 9 Agustus 1945, Amerika Serikat menjatuhkan bom atom kedua, kali ini di kota Jepang Nagasaki, walaupun meleset satu mil dari sasaran, tapi membunuh 75.000 orang. ${ }^{8}$

Energi nuklir sebagai pembangkit listrik dengan menggunakan reaktor nuklir digunakan pertama kali pada Tanggal

\footnotetext{
${ }^{7}$ Sejarah Terciptanya Bom Nuklir, diakses dari:

http://www.centralartikel.com/2010/10/sejar ah-terciptanya-bom-nuklir.html. pada $1 \mathrm{Mei}$ 2011

8 Sejarah Terciptanya Bom Nuklir, diakses dari: http://www.centralartikel.com/2010/10/ sejarah-terciptanya-bom-nuklir.html. pada 1 Mei 2011
}

20 desember 1951 di dekat kota Arco, Idaho. Energi yang dihasilkan sekitar $100 \mathrm{~kW}$. Dari tahun ke tahun kapasitas energi dari reaktor nuklir mengalami perkembangan pesat. Pada Tahun 1960, 1 gigawatt energi dihasilkan, sedangkan pada tahun 1970, 100 gigawatt dihasilkan, dan pada Tahun 1980300 giga watt energi nuklir dihasilkan. Setelah Tahun 1980 kapasitas energi yang dihasilkan tidak terlalu meningkat pesat. Sampai Tahun 2005 ini, baru 366 gigawatt energi dihasilkan. ${ }^{9}$

Kata "tenaga nuklir" sudah bukan lagi merupakan kata asing untuk didengar, tetapi sesungguhnya tidak semua orang mengetahui dengan pasti tentang tenaga nuklir. Sebagian masyarakat beranggapan bahwa tenaga nuklir merupakan sebuah kata untuk menyatakan suatu alat yang maha dahsyat yang dapat membahayakan keselamatan banyak orang. Segala hal yang berkaitan dengan pemanfaatan, pengembangan, dan penguasaan ilmu pengetahuan dan teknologi nuklir serta pengawasan kegiatan yang berkaitan dengan tenaga nuklir dikenal dengan istilah ketenaganukliran. Di Indonesia khususnya, mengenai ketenaganukliran tersebut diatur dalam Undang-Undang Republik Indonesia Nomor 10 Tahun 1997 Tentang Ketenaganukliran. Pengertian tenaga nuklir dimuat didalam Pasal 1 butir 2 Ketentuan Umum.

Menurut Kamus Besar Bahasa Indonesia, Nuklir adalah sesuatu yang berhubungan dengan atau

\footnotetext{
9 Sejarah dan Penggunaan Energi Nuklir, diakes dari: http://blogtriks.blogspot.com/2010/11/sejarah-danpenggunaan-energi-nuklir.html. pada $1 \mathrm{Mei}$ 2011
} 
menggunakan inti atau energi (tenaga) atom, ${ }^{10}$ sedangkan tenaga nuklir adalah sumber penggerak yang berasal dari nuklir. ${ }^{11}$ Di dalam ketentuan umum Undang-Undang Nomor 10 tentang Ketenaganukliran, tenaga nuklir adalah tenaga dalam bentuk apa pun yang dibebaskan dalam proses transformasi inti, termasuk tenaga yang berasal dari radiasi pengion. ${ }^{12}$ Dengan kata lain, tenaga nuklir adalah tenaga yang berasal dari inti atom yang dapat menghasilkan tenaga luar biasa besarnya.

Tenaga nuklir yang berasal dari radiasi pengion adalah kata lain dari radiasi nuklir. Radiasi nuklir berasal dari bahan radioaktif yang secara alami aktif memancarkan "sinar". Sinar tersebut terdiri atas tiga bagian yaitu sinar alpha, beta dan gamma. Temuan sinar gamma yang dikenal dengan sinar $\mathrm{X}$ memberikan manfaat yang sangat besar bagi dunia kedokteran. Sinar beta dan sejenisnya yang kemudian kita kenal sebagai sinar laser sangat bermanfaat antara lain bagi dunia konstruksi. Sinar alpha merupakan sinar radioaktif, dan partikel alpha kita kenal sebagai atom helium dan atom hidrogen. ${ }^{13}$ Radiasi nuklir tidak terlihat dengan mata telanjang, hanya dapat dideteksi dengan peralatan

\footnotetext{
10 Departemen Pendidikan Nasional dan Kebudayaan, Kamus Besar Bahasa Indonesia, (Jakarta: Balai Pustaka, 1989), hlm.618

11 Defenisi Tenaga Nuklir, diakses dari: http://www.artikata.com/arti-354070tenaga+nuklir.html. Pada 1 Mei 2011

12 Pasal 1 butir 2 Undang-Undang Republik Indonesia Nomor 10 Tahun 1997 Tentang Ketenaganukliran

13 Radiasi Nuklir, diakses dari: http://biologyandchemist.blogspot.com/2010 /04/radiasi-nuklir.html. pada 27 Mei 2011
}

(detektor) khusus, oleh karena itu terkadang manusia atau mahkluk hidup lainnya, sulit bahkan tidak menyadari saat terkena suatu radiasi nuklir. ${ }^{14}$

Radiasi menurut Kamus Besar Bahasa Indonesia adalah pemancaran dan kerambatan gelombang yang membawa tenaga melalui ruang atau zat antara, misalnya pemancaran dan perambatan gelombang elektromagnetik, gelombang bunyi, gelombang lenting, dan penyinaran, ${ }^{15}$ sedangkan di dalam Ketentuan Umum Undang-Undang Nomor 10 tentang Ketenaganukliran, radiasi pengion adalah gelombang elektromagnetik dan partikel bermuatan yang karena energi yang dimilikinya mampu mengionisasi media yang dilaluinya. ${ }^{16}$

Ketentuan Umum UndangUndang Nomor 10 tentang Ketenaganukliran menjelaskan juga tentang pemanfaatan atau penggunaan tenaga nuklir. Pemanfaatan atau penggunaan didefinisikan sebagai kegiatan yang berkaitan dengan tenaga nuklir yang meliputi penelitian, pengembangan, penambangan, pembuatan, produksi, pengangkut, penyimpanan, pengalihan, ekspor, impor, penggunaan, dekomisioning, dan pengelolaan limbah radioaktif untuk

\footnotetext{
${ }^{14}$ Penjelasan Bahaya Radiasi Nuklir untuk Masyarakat Umum, diakses dari: http://edukasi.kompasiana.com/2011/03/16/p enjelasan-bahaya-radiasi-nuklir-untukmasyarakat-umum/. Pada 23 mei 2011

15 Departemen Pendidikan Nasional dan Kebudayaan, Kamus Besar Bahasa Indonesia, (Jakarta: Balai Pustaka, 1989) ${ }^{16}$ Pasal 1 butir 3 Undang-Undang Republik Indonesia Nomor 10 Tahun 1997 Tentang Ketenaganukliran
} 
meningkatkan kesejahteraan rakyat. ${ }^{17}$ Bahan nuklir adalah bahan yang dapat menghasilkan reaksi pembelahan berantai atau bahan yang dapat diubah menjadi bahan yang dapat menghasilkan reaksi pembelahan berantai. ${ }^{18}$ Bahan nuklir terdiri atas : bahan galian nuklir, bahan bakar nuklir, dan bahan bakar nuklir bekas.

Bahan bakar nuklir adalah bahan yang dapat menghasilkan proses transformasi inti berantai. Bahan bakar fissil yang sering digunakan adalah 235U dan $239 \mathrm{Pu}$, dan kegiatan yang berkaitan dengan penambangan, pemurnian, penggunaan, dan pembuangan dari material-material ini termasuk dalam siklus bahan bakar nuklir yang berkaitan penting dengan PLTN dan senjata nuklir. ${ }^{19}$ Reaktor nuklir adalah alat atau instalasi yang dijalankan dengan bahan bakar nuklir yang dapat menghasilkan reaksi inti berantai yang terkendali dan digunakan untuk pembangkitan daya, atau penelitian, dan/atau produksi radio isotop, yang berlawanan dengan bom nuklir, dimana reaksi berantai tejadi pada orde pecahan detik, redaksi ini tidak tekontrol. ${ }^{20}$

Pemanfaatan nuklir dapat dikategorikan untuk makanan, obatobatan, kesehatan dan kedokteran, industri, transportasi, desalinasi air, listrik dan senjata. Pemanfaatan

\footnotetext{
17 Pasal 1 butir 4 Undang-Undang Republik Indonesia Nomor 10 Tahun 1997 Tentang Ketenaganukliran

18 Pasal 1 butir 5 Undang-Undang Republik Indonesia Nomor 10 Tahun 1997 Tentang Ketenaganukliran

19 Tito Adibaskoro. Energi Nuklir dan Alternatif Pembangkit Listrik Di Indonesia. (RajaGrafindo : Jakarta, 2008), hlm. 34.

${ }^{20}$ Ibid. hlm. 36.
}

radio isotop telah dilakukan untuk keperluan makanan yang berhubungan dengan rekayasa pertanian dan peternakan. Pemanfaatan bahan nuklir untuk obat-obatan, kesehatan, kedokteran dan industri juga diperolehdari radio isotop. Untuk transportasi dapat dibagi menjadi dua tipe, yaitu pemanfaatan langsung reaktor nuklir untuk transportasi dan pemanfaatan secara tak langsung dengan produksi hidrogendari kelebihan panas reaktor nuklir, yang nantinya hidrogen tersebut dapat dimanfaatkan sebagaibahan bakar.

Pemanfaatan reaktor nuklir berskala kecil untuk kendaraan telah dilakukan untuk keperluan eksplorasi di daerah terisolir seperti di kutub oleh pemerintah Rusia sekitar tahun 1950 an, hanya saja untuk skala kendaraan komersial masih belum bisa dilakukan. Dalam skala kapal selam telah banyak dilakukan dengan memanfaatkan reaktor kecil untuk menggerakkan mesin kapal selam tersebut. Pemikiran lain adalah untuk transportasi luar angkasa. Pemanfaatan energi nuklir untuk keperluan transportasi di atas khususnya kendaraan eksplorasi, kapal selam dan pesawat luar angkasa, dikarenakan pemanfaatan bahan nuklir yang dapat dilakukan untuk jangka yang relatif panjang tanpa adanya refueling (penambahan bahan bakar baru selama reaktor beroperasi). $^{21}$

Desalinasi air juga menjadi penting, khusunya berkurangnya

21 Disadur dari: Aprilia Fransiska S.H. Skripsi, Analisis Terhadap Hak dan Kewajiban Negara Anggota Badan Tenaga Atom Internasional (International Atomic Energy Agency/IAEA) Dalam Pemanfaatan Nuklir Untuk Tujuan Damai, hlm 15 
sumber air bersih bagi keperluan sehari-hari, hal ini juga memanfaatkan kelebihan panas dari sebuah reaktor nukir. Dalam skala industri yang lebih luas lagi, pemanfaatan bahan bakar nuklir untuk keperluan pembangkit listrik. Dari skala dunia, nuklir berkontribusi sekitar $17 \%$ untuk keperluan energi listrik dunia, dimana penghasil tertinggi energi listrik berbahan bakar nuklir adalah Amerika Serikat, yang mengambil $30 \%$ yaitu sebesar 763,7 BkWh. Kemudian diikuti oleh Prancis yang mengambil porsi $16,5 \%$ dan Jepang 9,5\% serta dengan beberapa negara lainnya.

Pemanfaatan nuklir untuk senjata merupakan hal yang terus hangat diperdebatkan terutama selepas perang dunia ke 2 dan perang dingin. Secara mendasar selain untuk tujuan perang, kesemua pemanfaatan bahan bakar nuklir berasal dari satu kebutuhan akan energi dan manfaatnya untuk manusia. Ada 2 pilihan secara filosofi berkaitan dengan bahan bakar nuklir ini, mau dimanfaatkan atau dibiarkan begitu saja. Pilihan untuk memanfaatkan bahan nuklir masih tersimpan dua pertanyaan lagi, yaitu memanfaatkan untuk keperluan sipil dan keperluan damai atau untuk pemanfaatan militer dan peperangan. Pemanfaatan untuk keperluan damai inilah disebut sebagai pembangkit tenaga nuklir (PLTN) atau nuclear power plant (NPP). Perkembangan teknologi nuklir sebagai energi alternatif yang dimanfaatkan menjadi energi listrik yang bisa menjadi kontributor kompetitif dengan sumber energi listrik lainnya seperti batu bara, minyak, gas, air dan lainnya. $^{22}$

Konsep keselamatan tenaga nuklir sangat penting dalam pemanfaatan tenaga nuklir, karena dibalik keuntungan-keuntungan yang dapat dirasakan dengan memanfaatkan tenaga nuklir, pemanfaatan tenaga nuklir sangat rawan akan terjadinya kecelakaan baik karena kelalaian manusia ataupun karena bencana alam. Oleh karena itu pemanfaatan tenaga nuklir harus memperhatikan semboyan atau azas keselamatan pemanfaatan nuklir. Setiap kegiatan yang berkaitan dengan pemanfaatan tenaga nuklir wajib memperhatikan keselamatan, keamanan, dan ketenteraman, kesehatan pekerja dan anggota masyarakat, serta perlindungan terhadap lingkungan hidup. $^{23}$

Berdasarkan alasan diatas, pada tanggal 17 Juni 1994 melalui konferensi diplomatik yang diselenggarakan oleh IAEA, telah terbentuk suatu konvensi tentang keselamatan tenaga nuklir yaitu Convention On Nuclear Safety (Konvensi Tentang Keselamatan Nuklir). Konvensi keselamatan nuklir mengandung konsepsi luhur akan arti pentingnya aspek budaya keselamatan instalasi nuklir secara global, untuk mencapai dan mempertahankan kualitas keselamatan nuklir yang tinggi di seluruh dunia, melalui peningkatan langkah-langkah atau kegiatan yang dilakukan secara nasional, dan kerjasama internasional. Konvensi keselamatan nuklir pada hakekatnya

\footnotetext{
${ }^{22}$ Ibid., hlm 16

${ }^{23}$ Pasal 16 butir 1 Undang-Undang Republik Indonesia Nomor 10 Tahun 1997 Tentang Ketenaganukliran
} 
akan memberi jaminan perlindungan bagi pekerja, masyarakat dan lingkungan hidup. Konvensi keselamatan nuklir mencakup tiga hal yaitu Instalasi nuklir dalam hal ini adalah PLTN, Badan Pengawas dan perizinan. ${ }^{24}$

Pemanfaatan tenaga nuklir dilakukan dalam suatu instalasi nuklir, seperti reaktor nuklir, baik reaktor untuk keperluan menghasilkan listrik maupun untuk tujuan riset dan produksi isotop untuk memenuhi kebutuhan rumah sakit, fasilitas pemurnian, fasilitas fabrikasi bahan bakar nuklir, fasilitas penyimpanan bahan bakar nuklir dan bahan bakar nuklir bekas. Termasuk dalam lingkup instalasi nuklir adalah instalasi radiometalurgi. Instalasi nuklir harus didesain dan dibangun serta dioperasikan sedemikian rupa sehingga pemanfaatan tenaga nuklir selamat dan aman.

Pemanfaatan tenaga nuklir, dari sejak dini telah dilakukan upaya pencegahan terhadap kemungkinan terjadinya kecelakaan radiasi dengan menerapkan prinsip pertahanan berlapis (defense in depth). Untuk kepentingan kesiapsiagaan dan penanggulangan kedaruratan nuklir, instalasi dibagi menjadi 5 (lima) kategori bahaya radiologi, yaitu:

a. Kategori I, yaitu instalasi dengan potensi bahaya sangat besar yang mampu menghasilkan lepasan radioaktif ke luar tapak instalasi sehingga memberi dampak

\footnotetext{
${ }^{24}$ Yusri Heni N.A., Suhartono Zahir2, Amil Mardha. Peranan Konvensi Keselamatan Nuklir Dalam Upaya Peningkatan Keselamatan PLTN Secara Global. Seminar Keselamatan Nuklir 2 - 3 Agustus 2006. Diakses dari: www.ansn-indonesia.org. pada 22 Mei 2011
}

deterministik serius terhadap kesehatan;

b. Kategori II, yaitu instalasi dengan potensi bahaya yang mampu menghasilkan lepasan radioaktif ke luar tapak instalasi dan menyebabkan meningkatnya dosis masyarakat sehingga memerlukan tindakan perlindungan segera;

c. Kategori III, yaitu instalasi dengan potensi bahaya tidak berdampak terhadap daerah di luar tapak instalasi tetapi memerlukan tindakan perlindungan segera pada tapak instalasi;

d. Kategori IV, yaitu kegiatan dengan potensi bahaya yang memerlukan tindakan perlindungan segera pada tempat yang tidak dapat diprediksi, termasuk kegiatan yang tidak memiliki izin; dan

e. Kategori V, yaitu kegiatan yang dalam keadaan normal tidak terkait dengan sumber radiasi pengion, tetapi dapat menghasilkan produk yang mempunyai kemungkinan terkontaminasi akibat kecelakaan yang terjadi pada instalasi dengan kategori bahaya radiologik I atau II, baik di dalam maupun di luar negara. ${ }^{25}$

Penggunaan tenaga nuklir pada saat ini sudah semakin berkembang. Salah satunya diakibatkan oleh perkembangan ilmu pengetahuan dan

\footnotetext{
25 Rapat harmonisasi RPP tentang Keselamatan dan Keamanan Instalasi Nuklir, diakses dari: http://www.djpp.depkumham.go.id/kegiatanumum/1155-rapat-harmonisasi-rpp-tentangkeselamatan-dan-keamanan-instalasinuklir.html. pada 22 Mei 2011
} 
teknologi, tetapi penggunaan tenaga nuklir yang dapat mengakibatkan dampak yang sangat buruk bagi makhluk hidup mengharuskan pemanfaatan tenaga nuklir hanya untuk tujuan damai, dan harus memeperhatikan semboyan atau azas keselamatan pemanfaatan nuklir, yaitu pemanfaatan tenaga nuklir harus mendapat pengawasan yang cermat agar selalu mengikuti segala ketentuan di bidang keselamatan tenaga nuklir sehingga pemanfaatan tenaga nuklir tersebut tidak menimbulkan bahaya radiasi terhadap pekerja, masyarakat, dan lingkungan hidup. ${ }^{26}$

Penggunaan tenaga nuklir juga menuntut sebuah tanggungjawab yang besar, karena tenaga nuklir memerlukan keselamatan dan keamanan yang tinggi, rawan terhadap penyimpangan untuk senjata, dan rawan digunakan untuk kejahatan teroris. Negara yang lalai menggunakan tenaga nuklir dan tidak sesuai dengan ketentuan hukum internasional dapat dibebankan suatu tanggungjawab negara untuk kerugian yang ditimbulkan kelalaian tersebut.

Beberapa ketentuan hukum internasional yang berkaitan dengan pemanfaatan nuklir untuk tujuan damai dan tanggungjawab negara akibat radiasi nuklir diantaranya adalah:

\section{a. Convention on Nuclear Safety (Konvensi Tentang Keselamatan Nuklir)}

\footnotetext{
26 Penjelasan atas Undang-Undang Republik Indonesia Nomor 10 Tahun 1997 Tentang ketenaganukliran, diakses dari: http://www.batan.go.id/prod_hukum/pnjelas _uu_tenuk.php. pada 13 September 2011
}

Konvensi keselamatan nuklir mengandung konsepsi luhur akan arti pentingnya aspek budaya keselamatan instalasi nuklir secara global, untuk mencapai dan mempertahankan kualitas keselamatan nuklir yang tinggi di seluruh dunia, melalui peningkatan langkah-langkah atau kegiatan yang dilakukan secara nasional, dan kerjasama internasional. Konvensi keselamatan nuklir pada hakekatnya akan memberi jaminan perlindungan bagi pekerja, masyarakat dan lingkungan hidup.

Tujuan konvensi berdasarkan ketentuan Pasal 1 adalah sebagai berikut:

1. Untuk mencapai dan mempertahankan tingkat keselamatan nuklir yang tinggi di seluruh dunia melalui peningkatan langkah-langkah atau kegiatan yang dilakukan secara nasional dan kerjasama internasional;

2. Untuk membangun dan memelihara pertahanan yang efektif dari instalasi nuklir terhadap bahaya radiologis, dan untuk melindungi individu, masyarakat dan lingkungan dari bahaya radiasi nuklir;

3. Untuk mencegah terjadinya kecelakaan nuklir yang menyebabkan bahaya radiologis dan untuk mengurangi bahaya radiologis tersebut.

Pasal 6 Convention on Nuclear Safety ini mengatakan bahwa setiap pihak wajib mengambil langkahlangkah tepat untuk memastikan bahwa keselamatan instalasi nuklir yang ada harus ditinjau ulang secepat mungkin agar sesuai dengan ketentuan konvensi ini, setiap pihak juga harus memastikan bahwa semua perbaikan telah dilakukan untuk 
meningkatkan keselamatan instalasi nuklir. Jika perbaikan tersebut tidak dapat dipenuhi, maka harus direncanakan untuk menutup instalasi nuklir tersebut secepat mungkin.

Each Contracting Party shall take the appropriate steps to ensure that the safety of nuclear installations existing at the time the Convention enters into force for that Contracting Party is reviewed as soon as possible. When necessary in the context of this Convention, the Contracting Party shall ensure that all reasonably practicable improvements are made as a matter of urgency to upgrade the safety of the nuclear installation. If such upgrading cannot be achieved, plans should be implemented to shut down the nuclear installation as soon as practically possible. The timing of the shut-down may take into account the whole energy context and possible alternatives as well as the social, environmental and economic impact.

Pasal 10 Convention on Nuclear Safety juga mengatakan bahwa setiap pihak wajib mengambil langkah-langkah tepat untuk memastikan bahwa semua organisasi yang terlibat dalam kegiatan yang berhubungan langsung dengan instalasi nuklir harus menetapkan kebijakan yang lebih mengutamakan keselamatan nuklir.

Each Contracting Party shall take the appropriate steps to ensure that all organizations engaged in activities directly related to nuclear installations shall establish policies that give due priority to nuclear safety.

Konvensi ini juga mengharuskan setiap pihak untuk mengambil langkah yang tepat untuk memastikan tersedianya sumber daya keuangan yang memadai untuk mendukung keselamatan setiap instalasi nuklir, dan harus mengambil langkah yang tepat untuk memastikan tersedianya staf yang berkualitas dengan pendidikan yang tepat, pelatihan yang tepat dan berulang untuk semua kegiatan yang terkait dengan keselamatan setiap instalasi nuklir. Setiap pihak harus mengambil langkah yang tepat untuk memastikan bahwa dalam waktu pengoperasian instalasi nuklir maka paparan radiasi kepada pekerja dan masyarakat dari instalasi nuklir harus dijaga serendah mungkin dan setiap pihak harus memastikan bahwa tidak ada individu yang terkena radiasi nuklir yang melebihi dosis normal. Hal ini sesuai dengan ketentuan Pasal 15 Convention on Nuclear Safety ini.

Each Contracting Party shall take the appropriate steps to ensure that in all operational states the radiation exposure to the workers and the public caused by a nuclear installation shall be kept as low as reasonably achievable and that no individual shall be exposed to radiation doses which exceed prescribed national dose limits.

Konvensi tentang keselamatan nuklir ini menjadi sangat penting peranannya karena konvensi ini mempunyai tujuan untuk melibatkan secara legal partisipasi dari negaranegara yang mengoperasikan PLTN untuk menjaga keselamatan tingkat tinggi dengan menetapkan standarstandar internasional keselamatan nuklir yang harus dianut negaranegara tersebut dalam hal pemanfaatan nuklir untuk tujuan damai. 


\section{b. The Convention on the Physical Protection of Nuclear Material (Konvensi Tentang Perlindungan Fisik Bahan Nuklir)}

Konvensi ini diadopsi tanggal 26 Oktober 1979 di Wina, Austria, dan mulai berlaku efektif pada 8 Februari 1987. Indonesia menandatangani Konvensi ini pada tanggal 3 Juli 1986 dan meratifikasinya pada 5 November $1986 .{ }^{27}$ Pasal 2 konvensi ini mengatakan bahwa konvensi ini berlaku untuk bahan nuklir yang digunakan untuk tujuan damai ketika masih dalam tahap pengangkutan atau perjalanan atau masih dalam proses penyimpanan di dalam negeri, selanjutnya Pasal 3 mengatakan setiap negara harus mengambil langkah yang tepat dalam kerangka hukum nasional dan sesuai dengan hukum internasional untuk menjamin bahwa selama bahan nuklir diangkut melalui wilayahnya, atau pada kapal atau pesawat udara di bawah yurisdiksinya harus dilindungi pada tingkat yang diuraikan dalam Lampiran I.

Each State Party shall take appropriate steps within the framework of its national law and consistent with international law to ensure as far as practicable that, during international nuclear transport, nuclear material within its territory, or on board a ship or aircraft under its jurisdiction insofar as such ship or aircraft is engaged in

\footnotetext{
27 Perjanjian Internasional Ketenaganukliran, diakses dari: http://sainsindonesia. wordpress.com/2010/10/06/perjanjianinternasional-ketenaganukliran-padapenggunaan-nuklir-tujuan-damai/. Pada 20 November 2011
}

the transport to or from that State, is protected at the levels described in Annex I.

Pasal 4 The Convention on the Physical Protection of Nuclear Material ini menjelaskan beberapa kewajiban para pihak dalam konvensi ini, diantaranya adalah:

1. Setiap negara tidak akan mengekspor atau mengizinkan ekspor bahan nuklir kecuali negara tersebut yang telah menerima jaminan bahwa bahan nuklir tersebut akan dilindungi selama proses pengangkutan;

2. Setiap negara tidak akan mengimpor atau mengizinkan impor bahan nuklir kecuali negara pihak yang telah menerima jaminan bahwa materi tersebut akan dilindungi selama proses pengangkutan;

3. Suatu negara tidak akan mengijinkan bahan nuklir transit di wilayahnya atau melalui bandara atau pelabuhan di wilayahnya kecuali negara tersebut telah menerima jaminan bahwa bahan nuklir tersebut akan dilindungi selama proses pengangkutan;

4. Setiap negara wajib menerapkan dalam kerangka hukum nasional perlindungan fisik bahan nuklir sebagaimana digambarkan dalam Lampiran I untuk bahan nuklir yang diangkut dari wilayah suatu negara ke wilayah negara lain yang melalui perairan internasional atau wilayah udara yang sama.

Konvensi Tentang Perlindungan Fisik Bahan Nuklir ini mempunyai tujuan dan peranan yang sangat mendukung pemanfaatan tenaga nuklir untuk tujuan damai, karena konvensi ini bertujuan untuk mencapai tingkat keselamatan nuklir 
yang tinggi di seluruh dunia sehingga pemanfaatan tenaga nuklir untuk tujuan damai dapat tercapai dengan maksimal. Keselamatan nuklir tersebut akan diperkuat oleh pengembangan dan penerapan langkah-langkah yang memadai terhadap perlindungan fisik bahan nuklir dari pencurian atau penyimpangan bahan nuklir dan terhadap sabotase fasilitas nuklir.

\section{Penutup}

Berdasarkan pembahasan di atas, dapat diambil simpulan bahwa pada dasarnya Hukum internasional mengatur penggunaan nuklir untuk tujuan damai sebagaimana diatur dalam Pasal 13 butir 1 bagian $b$ Piagam Perserikatan Bangsa-Bangsa, dengan alasan tidak bertentangan dengan tujuan-tujuan dan prinsipprinsip dasar yang termuat di dalam Perserikatan Bangsa-Bangsa. Selain itu juga diatur dalam Convention on Nuclear Safety (Konvensi Tentang Keselamatan Nuklir) dan The Convention on the Physical Protection of Nuclear Material (Konvensi Tentang Perlindungan Fisik Bahan Nuklir).

\section{DAFTAR PUSTAKA}

Departemen Pendidikan Nasional dan Kebudayaan, 1989, Kamus Besar Bahasa Indonesia, Balai Pustaka, Jakarta.

Mukhlis Akhadi, 1997, Pengantar Teknologi Nuklir, Rineka Cipta, Jakarta.

Tito Adibaskoro, 2008. Energi Nuklir dan Alternatif Pembangkit Listrik Di Indonesia. Raja Grafindo Persada: Jakarta.
Konvensi Tentang Keselamatan
Nuklir

Konensi Tentang Perlindungan Fisik Bahan Nuklir Tahun 1979

Undang-Undang Republik Indonesia Nomor 10 Tahun 1997 Tentang ketenaganukliran 